\title{
Functions, Assets and Risk Analysis in the Preparation of Transfer Pricing Documentation
}

\author{
Mariana I. Muzychuk*, Olena V. Fomina \\ Department of Accounting and Taxation, Faculty of Finance and Accounting, Kyiv National University of Trade and Economics, \\ 19 Kioto Street, 02156, Kyiv, Ukraine
}

Received July 2, 2021; Revised August 10, 2021; Accepted September 21, 2021

\begin{abstract}
Cite This Paper in the following Citation Styles
(a): [1] Mariana I. Muzychuk, Olena V. Fomina, "Functions, Assets and Risk Analysis in the Preparation of Transfer Pricing Documentation," Universal Journal of Accounting and Finance, Vol. 9, No. 5, pp. 935 - 945, 2021. DOI: 10.13189/ujaf.2021.090505.
\end{abstract}

(b): Mariana I. Muzychuk, Olena V. Fomina (2021). Functions, Assets and Risk Analysis in the Preparation of Transfer Pricing Documentation. Universal Journal of Accounting and Finance, 9(5), 935 - 945. DOI: 10.13189/ujaf.2021.090505.

Copyright $\odot 2021$ by authors, all rights reserved. Authors agree that this article remains permanently open access under the terms of the Creative Commons Attribution License 4.0 International License

\begin{abstract}
The topicality of scientific and applied research, which was aimed at developing and improving methods of tax administration of transfer pricing, is the relative novelty of the active use of this tool. It is worth noting that almost all elements of the mechanism for determining the value of the transaction, the operations of which are recognized as controlled, including the procedures for conducting functional analysis for the preparation of transfer pricing documentation. This allowed stating the aim of the publication, which is to identify the features of functional analysis to justify the choice of the comparative side of the controlled operation in Ukraine, as well as the method of ensuring compliance with the arm's length principle and organisation of the reporting process. The organisational and legal support of the functional analysis for the purposes of transfer pricing and the use of its results in the preparation of transfer pricing reports were studied. The study revealed incomplete organisational and legal conditions for preparing a transfer pricing report in Ukraine, in particular, difficulties in obtaining information for comparisons, as well as the lack of a unified methodology for functional analysis to reveal the economic nature of the transaction, which is considered controlled for transfer pricing purposes. Based on a positive and regulatory analysis of the processes of forming the market value of the transaction for tax purposes, the author's vision of the methodological approaches to functional analysis in Ukraine, presented in the Practical Manual on Transfer Pricing for Developing Countries 2021, was proposed.
\end{abstract}

Keywords International Taxation, Transfer Pricing, Controlled Transaction, Functions, Assets And Risk (FAR), Functions, Risks, Assets

\section{Introduction}

In the context of globalization, there are transformations of the geographical and socio-economic profile of the economic system. The geography of placement of productive forces, the sectoral landscape of the world economy are formed under the influence of the intensification of information and technological exchange, taking into account the global market conditions. Economic crises and upturns have a global scale [1]. The author of $[2,3]$ addressed the impact of globalisation, international integration, technological progress on the distribution of the tax burden and the ability to mobilise budget revenues by developing countries at the beginning of the 3rd millennium.

The world economy is currently in a serious crisis caused by the COVID-19 pandemic. The self-isolation regime can significantly slow down the spread of coronavirus infection. However, such measures have led to a sharp reduction in GDP, investment, reduced mobility of employees. As a result, the stability and number of production chains and manufacturing base reduces, while capital mobility increases. 
These trends are also due to the new industrial revolution, the main feature of which is the accelerated development of IT and nanotechnology, as well as the digitalisation (digital transformation) of the economy. Accelerating the pace of technological change, leading to the reformatting of existing business models, opening new opportunities at all levels of state and social development, carries certain threats and an element of uncertainty [4]. Issues related to the tax regulation of digital business are currently being actively discussed [5], as a result many countries, including Ukraine, are amending their tax legislation.

According to UNCTAD on the development of international production, there is a general trend to reduce value chains, increase concentration of value added and reduce international investment in physical production assets. One of the main explanations for such trends is the consequences of the COVID-19 pandemic, the gradual reorientation in placement of institutional investment capital from manufacturing to promising infrastructure projects, as well as the development of renewable energy, water and sanitation, food industry, agriculture, healthcare [6].

According to preliminary UNCTAD estimates, the global inflow of foreign direct investment in 2020 decreased by $40 \%$ compared to 2019 . This is the volume of reduced profits of 5,000 international companies, which provide most of the world's foreign direct investment. At the same time, mergers and acquisitions in the sector of international corporations decreased by more than $50 \%$. These negative trends are taking place against the background of active work on reforming the international investment regime defined by UNCTAD [7].

It should be noted that the change in the profile of global investment distribution can be explained by the global trend of increasing control and transparency of capital movements, provided by the implementation of international norms and national laws in many countries, including recommendations and standards of the FATF, Egmont Group, Basel Committee, the Wolfsberg Group principles, Directive (EU) 2015/849 On the Prevention of the Use of the Financial System for the Purposes of Money Laundering or Terrorist Financing, Regulation (EU) 2015/847 On Information Accompanying Transfers of Funds, as well as the implementation of the BEPS (Base Erosion and Profit Shifting).

In September 2013, the OECD and the G20 countries adopted an Action Plan to address the BEPS issue. The initiative includes $15 \mathrm{key}$ actions in three main areas, namely the implementation of coherent national rules affecting international activities, strengthening the requirements of existing international standards on this matter, as well as improving transparency and confidence. Ukraine joined the BEPS inclusive framework on January 1,2017 , committing itself to implementing the minimum standard (steps 5, 6, 13, 14), and signed the Multilateral
International Convention (MLI) $[8,9]$ and also developed a roadmap for the implementation of its provisions in national legislation [10].

Annual changes in the tax legislation of Ukraine in the field of transfer pricing (hereinafter - the TP) and the growing number of disputes and violations that arise and are manifested in the TP administration indicate the high socio-economic importance of this issue. The TP rules raise many questions about their compliance in taxpayers' reports, in particular, in terms of justifying the level of transfer prices and methods of establishing compliance with the conditions of controlled transaction on the arm's length principle in the analysed transactions, what sources of information shall be used.

Despite the huge amount of work performed and the large number of fundamental and applied developments in the field of transfer pricing, there are still a number of problematic issues that require close attention of scholars and practitioners. One of the most important issues is the taxpayer's final report on transfer pricing. After all, national legislation contains a small list of reports, the data of which must be confirmed by the taxpayer at the supervisory authority's request. In addition, it is noteworthy that there are no legally approved methods of conducting procedures that are necessary for the preparation of such a report, in particular, in terms of functional analysis. Functions, Assets and Risk (FAR) analysis for transfer pricing purposes includes information about the functions of the parties to the transaction, the assets used related to the controlled transaction, and undertaken economic (commercial) risks, which the taxpayer took into account when concluding the transaction. The Tax Code of Ukraine establishes 21 main functions and 9 main risks and their criteria. The results of FAR analysis are the basis for choosing a method of justifying the price.

The imperfections of organisational and legal conditions and the lack of approved methodological approaches to the application of transfer pricing rules, due to the relative novelty of the practical application of this tax administration tool, as well as the complexity of modern financial and economic relations, determined the topicality of research and its aim. The aim of the article is to identify the features of the application of FAR analysis to justify the choice of the comparative side of the controlled transaction, as well as the method of ensuring compliance of such an transaction with the arm's length principle and organising the reporting process on these issues.

Achieving this aim involves a number of objectives, namely:

- identify shortcomings of existing approaches to accounting and analytical provision of taxpayers' reporting to the tax authorities on transfer pricing;

- study the organisational and legal provision of the FAR analysis for the purposes of transfer pricing and 
the use of its results in the preparation of reports on transfer pricing;

- develop and prepare proposals for amendments to the legislative framework of Ukraine on transfer pricing.

\section{Literature Review}

The main source of disputes between regulatory authorities and multinational companies (hereinafter $\mathrm{MNCs}$ ) is the proportions of the distribution of total income between the jurisdictions in which MNCs operate. After all, the redistribution of MNC revenues occurs using transfer (domestic) prices [11]. Price manipulation is recognised as one of the oldest and most common ways of tax evasion [12]. The main criterion that underlies almost all procedures related to the calculation of transfer prices is the criterion of independence of the parties to the transaction. The introduction of transparent and fair transfer pricing rules reduces the likelihood of conflict situations.

In the last century, the Organisation for Economic Co-Operation and Development (OECD) [13], the United Nations [14] and the European Community [15] agreed on the need to introduce common standards for calculating transfer pricing [16]. The OECD and the United Nations have developed options of the model conventions for the avoidance of double taxation, which proposed to regulate a wide range of transfer pricing issues [17]. Subsequently, the provisions of the UN and OECD conventions were amended as a result of the development and adoption of BEPS - base erosion and profit shifting as a result of MNCs' tax planning [18].

The issues of transfer pricing economics are widely covered [19]. The collection contains 50 articles by the most influential authors on transfer pricing with the coverage period 1955-2013. The collection discusses issues of organisational and legal provision, model decisions in terms of concluding interstate agreements to avoid double taxation, market distortions and product characteristics, as well as empirical assessments of the consequences of transfer prices manipulation.

In a broad sense, FAR analysis belongs to the section of analysis that studies infinite-dimensional topological vector spaces and their mappings. The most important examples of such spaces are function spaces, which determined the name of this research method - "FAR analysis" [20-23]. FAR analysis of socio-economic systems is carried out in order to identify and study the dynamic characteristics of the system (environment, including hierarchical relationships) by studying the process of change in its states over time. The objects of FAR analysis are control algorithms (methods, techniques, principles, concepts) used by the system, including the general algorithm of operation, which contains all the main stages (phases, functions) of control, ensuring the implementation of individual stages of control. The subject of FAR analysis is the selection and study of the most significant elements of the system (environment) and their functions [24].

At the beginning of its formation (early 20th century), FAR analysis, as a direction of mathematical analysis, was used in the exact sciences to study the Theory of Measures and Integration, functions, operators, and differential calculus in infinite-dimensional spaces. In the second half of the 20th century, FAR analysis was supplemented by a number of special sections related to management theory and optimization in particular. FAR analysis has recently been used for the purposes of tax administration of certain taxpayers' transactions, which are recognised as controlled for the purposes of transfer pricing.

The FAR analysis clarifies the causal relationships, interdependence and interaction of functions and environment (system). It is believed that the issue of dialectical relationship, interdependence and the relationship of structure (environment) and function is one of the oldest. When considering the structure and function, the primary change is traditionally recognized as a change of function. However, the reverse is also true, that is, the change of the environment leads to the transformation of the function, which, in turn, causes the reformatting of the structure (environment).

Functional, Assets and Risk (FAR) analysis is the basis of transfer pricing analysis. Based on its results, taxpayers and regulatory authorities decide on the choice of a particular method of determining the market value of the transaction, and the choice of comparative data to justify comparable conditions [25, 26].

\section{Research Model}

\subsection{Dynamics of BEPS Plan Implementation in Ukraine}

In Ukraine, full control over transfer pricing has been carried out since 2013. During this period, the State Tax Service of Ukraine processed more than 20 thousand taxpayers' reports. The predominant number of taxpayers' controlled transactions are transactions with goods (more than 50\%) and banking services (more than 30 percent), respectively. The main states (territories) in which non-resident counterparties are registered, and which account for two thirds of controlled banking transactions, are France and Russia, and for the rest of the transactions - Switzerland (32\%), Cyprus (10\%) and the UAE (7\%), respectively [27].

The controlling bodies of Ukraine on a regular basis carry out control and verification of taxpayers' compliance with the timeliness and completeness of declaring controlled transactions, as well as submission of TP documentation, which resulted in more than UAH 1 
milliard of corporate income tax and VAT. The largest number of violations of tax legislation is observed in transactions with residents of Switzerland. At the same time, taxpayers independently increase the financial results of transactions with residents of other countries.

Ukraine has consistently fulfilled its obligations as a party to the Convention and continues to work within the framework of the BEPS Action Plan [9]. Over the last two years, the criterion of recognising persons as related in the event that one person owns the corporate rights of another person has been increased to $25 \%$. The list of organizational forms of conducting business activities, which are subject to the criteria for recognising the persons as related, the list of criteria for recognising a transaction as controlled, has been expanded. A special method of transfer pricing has been introduced for complex cases of estimating the cost of compensation in the transfer of management functions of individual business processes or tangible assets. These provisions are provided for financial transactions in the updated OECD Guidelines [28]. Issues of transactions with commodities have been settled [29, 30], their list has been approved and the method of comparative uncontrolled price (comparison with quotation prices on the international market of goods) has been recommended for application. The reporting on controlled transactions has been improved, changes have been made to the form and Procedure for compiling the Report on Controlled Transactions.

Figure 1 shows that in 2020 Ukraine experienced a slowdown in real GDP growth. At the same time, the share of capital investment in GDP in 2020 decreased by 3.6 percentage points. On the other hand, the share of corporate income tax revenues in GDP did not fluctuate so sharply.

The dynamics of the share of corporate income tax revenues, capital investment in GDP, as well as real GDP growth have similar trajectories, and are in a direct but nonlinear relationship. The correlation coefficient of real GDP growth and the share of capital investment and corporate income tax revenues is 0.59 and 0.63 , respectively. At the same time, the share of corporate income tax revenues and capital investment in GDP is more closely correlated -0.83 .

\section{Compiled by the authors according to the State Statistics Service of Ukraine}

These trends indicate the effectiveness of the fiscal authorities of Ukraine in terms of improving the administration of tax revenues, including the consistent implementation of the main provisions of the BEPS plan. However, the negative trend in the reduction of capital investment in the medium term will lead to a slowdown in real GDP growth and, as a consequence, a natural narrowing of the corporate income tax base.

Therefore, the development and implementation of innovations in taxation, especially capital taxation, should be based on specific calculations with sound justification, taking into account the balance of interests of state and business with the main emphasis on sustainable economic development.

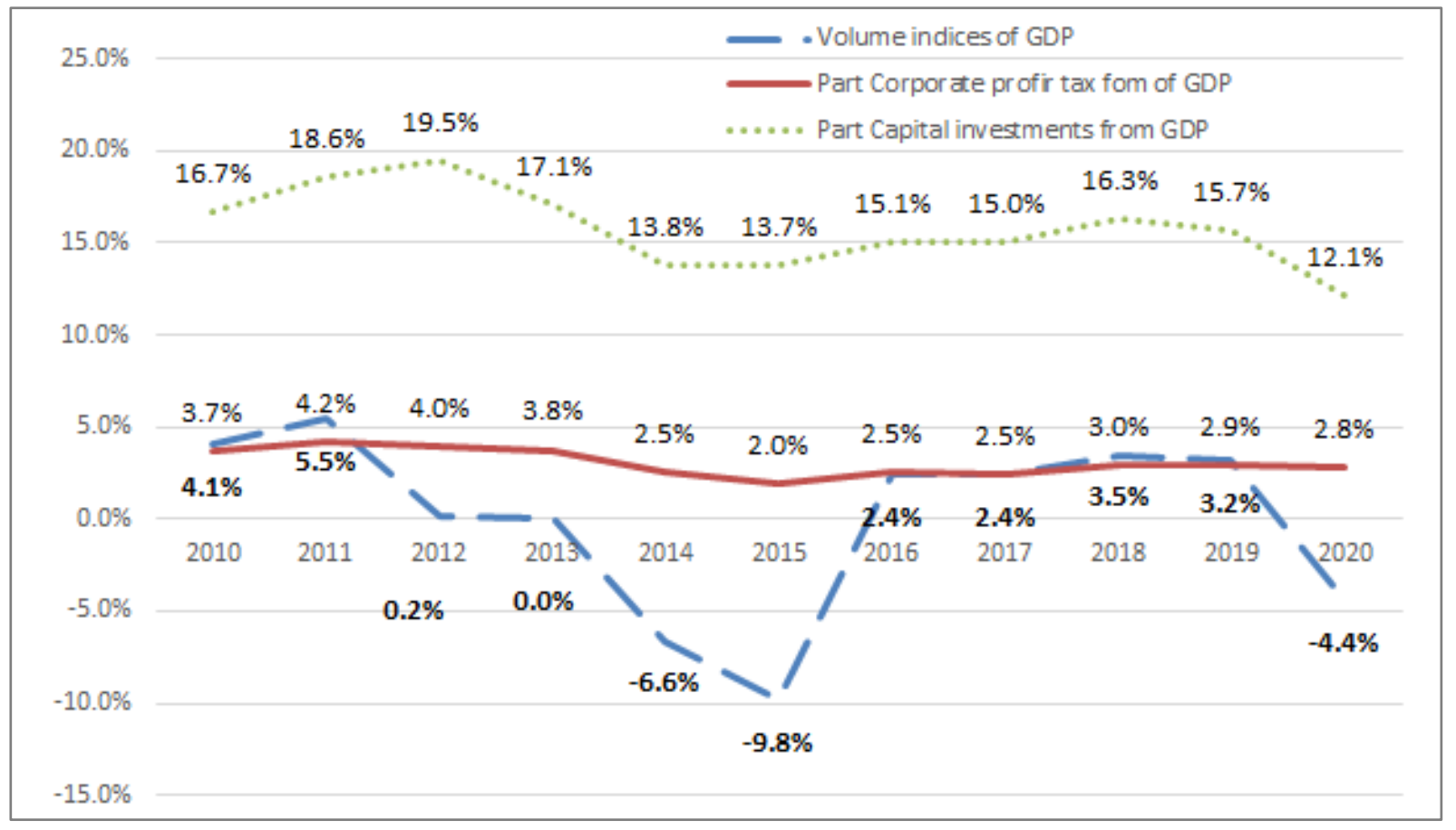

Figure 1. Dynamics of the share of capital investment and corporate income tax revenues in GDP, and real GDP growth for 2010-2020. 
However, the renewal of Ukraine's legislative field on transfer pricing has not reduced tensions between taxpayers and regulators. One of the reasons for this state of affairs is the lack of methodological approaches to conducting certain procedures to ensure the market price level of the controlled transactions approved at the national level, in particular to carry out FAR analysis. In particular, there is currently no standardised method of performing FAR analysis for transfer pricing in Ukraine. The updated reporting forms provide general information about the participants with details of the related parties by relation code, as well as the subject of the controlled transaction. The taxpayers prepare rest of the documentation in any form, guided by the expediency of detailing information in certain areas. This can lead to disputes between taxpayers and regulators, which in practice are often resolved in court. During 2020, there were many disputes in the courts over transfer pricing, most of which were resolved in favour of taxpayers [31].

\subsection{Transactions Comparability Analysis}

The OECD [32] and United Nations [33] transfer pricing guidelines offer a number of model solutions for conducting a transaction comparability analysis. In particular, there are five main economically significant characteristics or comparability factors, which should be taken into account in qualifying the transaction, its recognition as controlled or uncontrolled:

1. The terms of the transactions are enshrined in the contract;

2. The functions performed by each of the parties to the transaction, including their relation to the value creation function of the group of companies;

3. Characteristics of the assets used and/or services provided;

4. The economic situation of the parties and the situation in the market in which the transaction is implemented;

5. Business strategy followed by the parties to the transaction.

The full analysis of transfer pricing is based on the facts revealed in FAR analysis. Its results are the basis for determining the amount of compensation to a resident of a particular jurisdiction, in which most of the earned income will remain. Every detail is important here, such as the characteristics of the economic essence of the controlled transaction, the managing party to the transaction and the party to the limited risk transaction. A number of recommendations on the application of the arm's length principle in the extractive industry, in particular, the list and characteristics of the information to be collected for the audit of transfer prices can be found [34]. These conclusions will further allow choosing the most acceptable method of justifying the price parameters of the transaction for the purposes of transfer pricing for each transaction and the amount of profit if the analysis is profit-based.

The process of carrying out functional analysis for the purposes of transfer pricing involves structuring and organising actual information about the functions and roles of related parties to the transaction, based on the characteristics of the functional profiles of the parties to the transaction. International companies identify the entity that oversees the functions, make the assets available for use, and assume the risks associated with the transaction.

Functional analysis provides research that reviews the value chain process in the supply chain as a whole, as well as related party transactions. As a result, the contribution of each of the participants in the transaction and its role in the formation of the company's total profit is established.

The functions performed by the company and the risks assumed have a significant impact on its profitability. Usually, the functions correlate with the risks and assets involved in the transaction. Functions are bound with the value elements of the business, that is, the economic value of the functions in the process of making a profit. After all, control over the functions that provide the greatest influence on the generation of profits, gives grounds to the supervisory authorities of a particular jurisdiction to tax it in "their territory", that is in the city of generation of such profits.

Functional analysis is used to measure the relative contribution of the parties to the formation of the market value of products based on the study of economic and commercial factors. And its results provide grounds for the tax authorities of a particular jurisdiction to claim part of the profits generated as a result of such a transaction. After all, it is necessary to clearly understand the nature of commercial and financial relations between the parties to the transaction in order to apply the principles of market pricing to controlled transactions. This understanding allows choosing the most relevant method of ensuring the compliance of the transaction value with competitive conditions. A controlled transaction can be considered comparable to an uncontrolled one (concluded under the conditions of pure competition) in the absence of differences that significantly affect the transaction price. If such differences are identified, it is advisable to adjust the transaction price to eliminate such differences. In case of making such an adjustment by the controlling body, one will have to repay not only the accrued tax liabilities, but also pay a fine.

\subsection{Transactions Comparability Analysis}

The OECD Guidelines [32] state that in transactions between independent companies the transaction price reflects the functions of each company (commercial functions), which include the risks assumed and the assets used. After all, the concentration of functions, assets and commercial risks in a particular party to the agreement must be accompanied by the receipt of the main benefit. 
Therefore, the definition of competitive terms of agreements involves comparing the company's functions with similar functions of other unrelated companies. The information base for the purposes of FAR analysis is formed in the process of finding comparable companies (their financial statements), as well as comparable prices.

Functional analysis is an important and critical element of transfer pricing documentation, regardless of the type of transaction being declared - sale of goods (services), intercompany loan or insurance. Functional analysis identifies the functions, assets and risks that each entity uses and contributes to related party transactions. Analysis of the functions (involving borrowed assets and assumed risks) performed by associates (related companies) in controlled transactions and independent companies in comparable uncontrolled transactions is considered as the basis of the entire package of transfer pricing documentation. Such an analysis is recommended at the beginning of a comparative analysis in conjunction with a study of the economic activities of MNCs, including supply chains, market strategy and other elements on which comparisons are made [35].

Traditional FAR analysis of control systems includes the following main stages:

1. Definition and description of the general management process implemented by the studied system;

2. Decomposition of the general management process into a number of private functions (tasks, operations) performed by the elements of the management system;

3. Determination of qualitative and quantitative characteristics of the studied processes and management functions;

4. Formation of criteria and evaluation of the effectiveness of the management system;

5. Decision-making on the need to improve the functional characteristics of the management system.

FAR analysis for the purposes of transfer pricing allows determining the key areas of economic analysis, as well as the role of each entity in a particular transaction. The evidence base is formed in the course of functional analysis that income is taxed in the jurisdiction where value added is created. The results of functional analysis are used to select the most relevant method of transfer pricing. This method is based on the definition of its economic essence, which specifies the direction of the search for comparable data and significantly affects the results of the analysis.

Among the main problems faced by taxpayers in the course of FAR analysis is the lack of a unified methodology for this analysis, as well as insufficiency or lack in some regions of information on comparable transactions. The rule of choosing the "best method" involves determining the market price of the transaction by the method that, given the facts and circumstances, provides the "most accurate indicator". Thus, comparability and data quality are the two key factors that determine the best method [36].

The issue of methodological provision of functional analysis and the lack of reliable data for comparisons on transfer pricing has been discussed for a long time [37]. Many methodological approaches have been developed for the purposes of FAR analysis, which are set out in the form of guidelines, recommendations, etc. Leading international organizations, such As Organisation For Economic Co-Operation And Development (OECD); United Nations (UN); International Monetary Fund (IMF) and World Bank Group (WBG) [38] have established a special Platform to remove barriers to access to competitive materials, including through the development of special tools to assist developing countries. After all, in some cases (in some countries), obtaining information requires a special permission of the database provider, or such information is paid, or not available in the region. At the same time, the ambiguity of the interpretation of certain facts and conditions of the transaction by taxpayers and regulatory authorities leads to conflicts that are resolved in court.

A careful analysis of transfer pricing involves an understanding of the multinational company as a whole, in particular its organizational structure, operating infrastructure, including the location of each entity and the jurisdiction in which it participates in the overall business. Issues related to the supply of raw materials and energy resources, technologies and intangible assets are also studied in depth. A general and comprehensive view allows narrowing the essence of the functions performed by the parties to the transaction, that is to choose a meaningful list of functions for a particular transaction and not to analyse the activities of the whole entity in complex.

[39] identifies 12 steps in the functional analysis of a controlled transaction, which can be divided into 3 blocks. At the first stage, it is proposed to collect and study all the constituent documents and organisational structure of the entity. At the second stage it is necessary to cover the issues of documenting the developed products (availability of patents, certificates), labour costs. The functions of production, storage and sale (marketing) of products, as well as logistics and accounting are considered separately. Finally, the third block is the assessment of: market position (market share), contributed assets (working capital, tangible and intangible assets), and risks.

In the final report, it is recommended to identify a specific function performed by each organisation, that is production, invoicing, product distribution, marketing, advertising, procurement etc. This details the distribution of authority between the participants in a controlled operation and provides answers to traditional FAR questions: 
1. What function is performed within the corporation, that is not directly involved in the controlled transaction?

2. Which party is responsible for performing a specific function?

3. Where, who and to what extent perform the functions directly involved in the controlled transaction?

4. Which party provides direct control and overall management of the process?

An indicative list of issues for the purposes of the analysis of functions, risks and intangible assets is presented in Annex 1 of the Guidelines of the Platform for Collaboration on Tax [38].

An important point in conducting FAR is the detailed coverage of issues, because the R\&D function in the mining industry is significantly different from R\&D function in pharmaceutical industry. For example, the party under analysis is a limited risk distributor. It is compared to other limited risk distributors. The results of comparisons allow choosing the most relevant method of transfer pricing for each transaction and the profit level indicator in case when the analysis is profit-based.

The final report submitted to the supervisory authority shall contain a full analysis of transfer pricing, that is all the basic data identified in the course of FAR, in particular, the determination of the amount of independent compensation that each legal entity may claim and, accordingly, the taxes that remain in a particular jurisdiction.

After identifying the functions, the assets involved in the transaction, as well as their owners shall be determined. Tangible assets are relatively easy to identify. These are the main means of production (production equipment, buildings and structures, etc.) that are on the company's balance sheet. It is much more difficult to identify intangible assets in terms of ownership: trademarks, production processes, inventions. In this case, it is necessary to convincingly prove which of the parties performs the functions of development, improvement, maintenance, protection and operation, which are better known as DEMPE functions. The total volume of MNCs' intangible assets is on average equal to half the value of such companies [40].

In a broad sense, risk is always associated with threat and uncertainty, while being closely correlated with reward. A general definition of risk as the "impact of uncertainty on the achievement of objectives" as well as conceptual approaches to risk assessment and management are provided by ISO 31000:2009 [41] and the UN Guidelines on Risk Management in Regulatory Systems [42]. Transfer pricing risks are assessed and weighed in the same way as for other business transactions. After all, the entity that bears the greatest risk ultimately gets the biggest profit. FAR analysis allows finding out which side of the controlled transaction carries the greatest risk.
Typical risks that are assessed and weighed in the course of FAR analysis, as well as procedures for their analysis and weighing for the purposes of transfer pricing are provided in many policy documents, in particular OECD, UN, IMF and WBG [38] and United Nations [43] and discussed in scientific papers $[35,44]$. Understanding and reasonable proof in the FAR analysis of the party to the controlled transaction assuming the greatest risk is necessary to build a reliable comparative analysis, that is to find comparable transactions in which similar risks are distributed. It is the risk-reward ratio that allows determining the proportions of profit distribution in a controlled transaction.

The next step that follows defining the functions of each entity, as well as the risks assumed by each party to the transaction and the assets used to make a profit, is describing the business in a format that is relevant to the tax authorities. That is, it is necessary to make a careful description of the economic essence of the controlled transaction. For example, the characteristics of sales and distribution functions may be "sales agent", "limited risk distributor" or "full-fledged distributor". Production activity can be described as a "full-fledged producer" or "contracted manufacturer, outsourcing". At this stage, the question will be whether the business structure is restructured to minimise the tax burden within a large company or not.

\section{Results and Discussions}

Typically, transfer pricing is used in agreements between affiliated companies that are created within large multinational companies. It is believed that in case of cooperation of independent companies, the value of transactions is formed according to market laws. And in the case of interaction of related parties, it is traditionally assumed that the transaction price is distorted for the purpose of minimising tax liabilities within a group of those companies.

Transfer pricing is considered as a statutory and necessary characteristic of the economic activity of transnational companies. It is recognised that transfer prices may distort the distribution of taxable profits between the countries in which such a multinational company operates. This is the case when the price of the agreement between the related companies does not comply with recognised international standards [43].

The main goal of the MNCs is to maximise profits from the production of goods and services. The starting point for understanding how MNC works is the analysis of value chains, which is the basis of FAR analysis of transfer pricing. The chain of newly created value of MNC allows illustrating the process of transformation of its economic resources of lower value into economic resources of higher value. When comparing the added 
value chain for the industry with the chain for MNC, it is possible to identify factors of market advantage of MNC in the industry over competitors.

The United Nations Practical Manual on Transfer Pricing for Developing Countries [43] provides a methodology for conducting FAR analysis based on determining the intensity of the concentration of functions, risks and assets in a particular party to the transaction. The methodology can be used to summarise key aspects of functional analysis and qualitative comparison of different companies in the MNC in a number of categories related to the functions, assets and risks, based solely on the confirmed facts of a particular transaction (Table 1).

Table 1. Qualitative assessment of intragroup transactions

\begin{tabular}{|c|c|c|c|}
\hline Symbol & $\begin{array}{c}\text { Risk } \\
\text { comparison }\end{array}$ & $\begin{array}{c}\text { Functions } \\
\text { comparison }\end{array}$ & $\begin{array}{c}\text { Asset } \\
\text { comparison }\end{array}$ \\
\hline- & No risk & No functions & No assets \\
\hline$\sqrt{ } \sqrt{ }$ & The least risk & $\begin{array}{c}\text { The least } \\
\text { functions }\end{array}$ & $\begin{array}{c}\text { The least } \\
\text { assets }\end{array}$ \\
\hline$\sqrt{ } \sqrt{ }$ & $\begin{array}{c}\text { The highest } \\
\text { risk }\end{array}$ & $\begin{array}{c}\text { Thall } \\
\text { functions } \\
\text { function }\end{array}$ & $\begin{array}{c}\text { Medium } \\
\text { assets }\end{array}$ \\
\hline
\end{tabular}

Source: [43].

Weighing is proposed for each component of the FAR analysis to determine the intensity of functions, risks and use of assets by each party to a controlled transaction.

In order to reduce tensions in the area of coordination of transfer prices by business entities with regulatory authorities, as well as to reduce the level of subjectivity in determining the price level of a controlled transaction, it is advisable to consider a methodological approach based on UN proposals.

To do this, it is necessary to formalise the solution of the problem of determining the comparable party in the controlled transaction, that is the party that receives the main benefits. Since the definition of the comparable party is based on the assessment and comparison of functions, risks and assets involved, it can be argued that there is a functional relationship between these variables, which can be formalised as follows:

$$
\mathrm{C}=f(F ; R ; A)
$$

where $\mathrm{C}$ - comparable party to the controlled transaction, $\mathrm{F}$ - functions, $\mathrm{R}$ - risks, $\mathrm{A}$ - assets.

Typically, functions, risks and assets can be measured in monetary terms. In most cases, functions can be estimated by the cost of their performance. The total cost of the transaction or the total profit of its participants can also be taken as the base. Commercial risks are usually discussed in advance and assessed in monetary terms, as the risks are subject to insurance, in particular, captive (internal). As for assets, their current (residual) value is reflected in the financial and tax statements.

To ensure the comparability of these indicators, it is advisable to introduce special metrics that will allow to interpret and understand them. These characteristics can ensure the introduction of their thresholds and intermediate values. The range of characteristic values of each indicator can be measured from 0 to 3 and is divided into three intervals. This metric will ensure comparability with the methodological approaches proposed in the United Nations Practical Manual on Transfer Pricing for Developing Countries [43].

You can consider entering a wider range of indicator values, for example, from 0 to $100 \%$, which will increase their sensitivity.

$$
\mathrm{C}=\left(\sum F a+\sum R a+\sum A a\right)-\left(\sum F b+\sum R b+\sum A b\right)
$$

Table 2 shows an example of a comparison of intragroup transaction between company $\mathrm{A}$ and $\mathrm{B}$, which, according to its criteria, is considered controlled for the purposes of transfer pricing. The model presented in Equation 2 was used for comparison.

Table 2. An example of comparing an intragroup transaction between companies A and B

\begin{tabular}{|c|c|c|c|c|c|c|c|c|}
\hline Functions & A & B & Risks & A & B & Assets & A & B \\
\hline Product development & 0 & 3 & financial & 2 & 1 & tangible assets & 0 & 3 \\
\hline Production & 3 & 0 & production & 3 & 0 & intangible assets & 3 & 0 \\
\hline $\begin{array}{c}\text { General management } \\
\text { functions }\end{array}$ & 2 & 3 & market & 1 & 2 & & \\
\hline $\begin{array}{c}\text { Finance, accounting, } \\
\text { treasury and law }\end{array}$ & 2 & 3 & credit & 1 & 3 & & & \\
\hline $\begin{array}{c}\text { Human resource } \\
\text { management }\end{array}$ & 3 & 2 & currency & 1 & 3 & & 3 & 3 \\
\hline Total & 10 & 11 & & 8 & 9 & & 3 \\
\hline
\end{tabular}

Source: developed by the author using Equation 2. 
Using Equation 2, we can determine the party that is most likely to be compared in the example shown in Table 2.

$$
\mathrm{C}=(10+8+3)-(10+9+3)=-2
$$

A negative value of the indicator will mean that the party to the transaction that needs to be compared for the purposes of transfer pricing is Company B.

This methodological approach can be proposed for implementation as a separate block of Order of the Ministry of Finance of Ukraine No. 841 dated 31.12.2020 "On Amendments to the Form and Procedure for Compiling the Report on Controlled Transactions". Its adoption will reduce tensions in the area of tax administration of transfer pricing, as it will simplify the procedure for proving that the taxpayer (or supervisory authority) is right to choose the most appropriate method of establishing compliance with the arm's length principle in determining the price of a particular transaction.

\section{Conclusions}

The main problem faced by taxpayers in preparing a transfer pricing report is the lack of a unified methodology for preparing reporting documents, in particular, in terms of economic and functional analysis, as well as insufficient information, in some regions - lack of information on comparable agreements. The choice of the "best method" of determining the tax base involves establishing the market price of the transaction by a method that, given the facts and circumstances, prevents disputes between taxpayers and regulatory authorities.

Transfer pricing is provided by law and is a necessary attribute of the economic activity of MNCs. Transfer pricing is used in transactions between affiliated companies that are created under large MNCs of different profiles. Transfer pricing distorts the distribution of taxable profits between the countries in which such MNC operates when the transaction price between affiliated companies does not comply with recognised international standards. In the case of related party interaction, it is considered that the transaction price does not comply with market laws and is distorted for the purpose of minimising tax liabilities within the group of companies.

The key factors that shape the functional profile of the parties to a controlled transaction include: party relation criteria, other criteria for recognising a transaction as controlled, such as the volume of the transaction or annual turnover, as well as the conditions under which business transactions are recognised as the arm's length principle, in particular, the functions, risks and assets involved in the controlled transaction, the ability to access verified competitive information.

The study revealed imperfections of the organisational and legal framework for declaring the results of economic activity on transfer pricing in Ukraine. The main problems remain difficulties in obtaining reliable information for comparisons, as well as the lack of a unified methodology for FAR analysis to reveal the economic essence of the controlled transaction. In order to improve and develop the mechanism of administration of transfer pricing in Ukraine, a variant of the methodological approach to FAR analysis is proposed, as the development of the approach proposed in the Practical Manual on Transfer Pricing for Developing Countries 2021.

As the promising area of further research, it is advisable to consider the possibility of developing and implementing an automated system for evaluating the transaction for compliance of its price with the arm's length principle based on improving information and analytical support of transfer pricing administration, including by creating a single unified database to determine the comparability of the transaction terms.

\section{REFERENCES}

[1] K. Schwab. The Global Competitiveness Report, World Economic Forum, Geneva, 2019.

[2] V. Tanzi. Globalization and the work of fiscal termites, Finance \& Development, Vol. 38, No. 1, 2001. Online available from https://www.imf.org/external/pubs/ft/fandd/ 2001/03/tanzi.htm\#author

[3] V. Tanzi. Globalization and the need for fiscal reform in developing countries, Journal of Policy Modeling, Vol. 26, No. 4, 525-542, 2004.

[4] International Monetary Fund (IMF). World Economic Outlook, October 2020: A Long and Difficult Ascent, International Monetary Fund, Washington, D. C., 2020.

[5] M. Olbert, C. Spengel. Taxation in the Digital Economy Recent Policy Developments and the Question of Value Creation, ZEW, Mannheim, 2019.

[6] United Nations Conference on Trade and Development (UNCTAD). World Investment Report 2020. International Production Beyond the Pandemic, UNCTAD, Geneva, 2020.

[7] United Nations Conference on Trade and Development (UNCTAD). Recent Developments in the International Investment Regime: Taking Stock of Phase 2 Reform Actions. Note by the UNCTAD Secretariat. UNCTAD, Geneva, 2019.

[8] Verkhovna Rada of Ukraine. Multilateral Convention on the Implementation of Measures Relating to Tax Agreements, in Order to Counteract the Erosion of the Tax Base And the Withdrawal of Profits from Taxation, 2018. Online available from https://zakon.rada.gov.ua/laws/show /376_001-16\#n2

[9] Verkhovna Rada of Ukraine. The Law of Ukraine "On Amendments to the Tax Code of Ukraine and Other Laws of Ukraine on Ensuring the Collection of Data and Information Necessary for Declaring Certain Objects of 
Taxation", 2020. Online available from https://zakon.rada.g ov.ua/laws/show/1117-20\#Text

[10] Ministry of Finance of Ukraine. BEPS Action Plan: Key Aspects for Ukraine, 2020. Online available from https://www.mof.gov.ua/storage/files/2020_BEPS.pdf

[11] W. J. McCarten. International transfer pricing and taxation, In M. P. Shome, Tax Policy Handbook, 221-225, International Monetary Fund, Washington, D. C., 1995.

[12] G. F. Kopits. Intra-firm royalties crossing frontiers and transfer-pricing behaviour, The Economic Journal, Vol. 86, No. 344, 791-805, 1976.

[13] Organisation for Economic Co-Operation and Development (OECD). Transfer Pricing and Multinational Enterprises, OECD, Paris, 1979.

[14] United Nations. Tax Treaties between Developed and Developing countries, Seventh report, United Nations, New York, 1978.

[15] O. Ruding. Report of the Committee of Independent Experts on Company Taxation. Executive summary, Office for Official Publications of the European Communities, Luxembourg, 1992.

[16] M. Daly. Harmonization of Corporate Taxes in a Single European Market: Recent Developments and Prospects, 1992. Online available from https://heinonline.org/HOL/La ndingPage $?$ handle $=$ hein.journals $/$ cdntj40\&div=71\&id=\&p age $=$

[17] Organisation for Economic Co-Operation and Development (OECD). Model Tax Convention on Income and on Capital: Condensed Version September 1992, OECD, Paris, 1992.

[18] Organisation for Economic Co-Operation and Development (OECD). Action Plan on Base Erosion and Profit Shifting, OECD. Paris, 2013.

[19] L. Eden. The Economics of Transfer Pricing, Edward Elgar Publishing Ltd, Northampton, 2019.

[20] S. Banakh. Course of Functional Analysis (Lineal Operations). Radyanska Shkola, Kyiv, 1948.

[21] A. M. Kolmogorov, S. V. Fomin. Elements of Function Theory and Functional Analysis, Vyscha Shkola, Kyiv, 1974.

[22] E. Kreyszig. Introductory Functional Analysis with Applications, John Wiley \& Sons, New York, 1978.

[23] A. B. Linnik, G. N. Timchenko. The history of functional analysis development, The Bulletin of Kharkiv Polytechnic Institute, Vol. 20, 77-81, 2011.

[24] V. K. Halitsyn. Structural and Functional Analysis and Modeling of Economic Development: Monograph, KNEU, Kyiv, 2013.

[25] M. Lang, G Cottani, R. Petruzzi, A. Storck. Fundamentals of Transfer Pricing: A Practical Guide, Kluwer Law, Amsterdam, 2018.

[26] C. Plesner Rossing, M. Cools, C. Rohde. International transfer pricing in multinational enterprises, Journal of Accounting Education, Vol. 39, 55-67, 2017.
[27] State Tax Service of Ukraine. Results of Transfer Pricing Control for 2013-2020, 2021. Online available from https://tax.gov.ua/diyalnist-/transfertne-tsinoutvorenn/zagal ni-vidomosti/

[28] Organisation for Economic Co-Operation and Development (OECD). Transfer Pricing Guidance on Financial Transactions Inclusive Framework on BEPS: Actions 4 , 8-10. OECD, Paris, 2020.

[29] Cabinet of Ministers of Ukraine. Order of the Cabinet of Ministers of Ukraine "On Approval of the List of States (Territories) that Meet the criteria Established by Subparagraph 39.2.1.2 of Subparagraph 39.2.1 of Paragraph 39.2 of Article 39 of the Tax Code of Ukraine, and Recognition as Invalid, 2017. Online available from https://zakon.rada.gov.ua/laws/show/1045-2017-\%D0\%BF \#Text

[30] Cabinet of Ministers of Ukraine. Resolution of the Cabinet of Ministers of Ukraine "On Approval of the List of Raw Materials and Recognition as Invalid", 2020. Online available from https://zakon.rada.gov.ua/laws/show/1221-2 020-\%D0\%BF\#Text

[31] Supreme Court of Ukraine. Review of the Case Law of the Supreme Court in the Field of Transfer Pricing and International Taxation, 2020. Online available from http://www.visnuk.com.ua/uk/news/100021110-ttsu-sudov a-praktika

[32] Organisation for Economic Co-Operation and Development (OECD). Transfer Pricing Guidelines for Multinational Enterprises and Tax Administrations 2017, OECD, Paris, 2017.

[33] United Nations. Practical Manual on Transfer Pricing for Developing Countries. United Nations, New York, 2017.

[34] P. Guj., S. Martin, B. Maybee, F. Cawood, B. Bocoum, N. Gosai, S. Huibregtse. Transfer Pricing in Mining with a Focus on Africa. A Reference Guide for Practitioners, World Bank, Washington, D. C., 2017.

[35] J. Cooper, R. Fox, J. Loeprick, K. Mohindra. Transfer Pricing and Developing Economies. A Handbook for Policy Makers and Practitioners, World Bank, Washington, D.C., 2016.

[36] R. Feinschreiber. Transfer Pricing Methods: An Applications Guide. John Wiley \& Sons, Inc, New York, 2004.

[37] Organisation for Economic Co-Operation and Development (OECD). Part 1 of a report to G20 development working group on the impact of BEPS in low income countries, OECD, Paris, 2014. 1.

[38] Organisation for Economic Co-Operation and Development (OECD), United Nations (UN), International Monetary Fund (IMF), World Bank Group (WBG). Toolkit on comparability and Mineral Pricing, 2021. Online available from https://www.tax-platform.org/sites/pct/files/publicati ons/toolkit-on-comparability-and-mineral-pricing-RU.pdf

[39] R. F. Reilly. Functional analysis in the intellectual property valuation, damages, or transfer price measurement, Les Nouvelles-Journal of the Licensing Executives Society, Vol. 55, No. 44, 215-231, 2020. 
[40] Brand Finance. Global Intangible Finance Tracker (GIFT ${ }^{\mathrm{TM}}$ ) 2018 (An Annual Review of the World's Intangible Value), Brand Finance, Dallas, 2018.

[41] International Organization for Standardization (ISO), The International Electrotechnical Commission (IEC). Risk Management — Risk Assessment Techniques. International Organization for Standardization, Geneva, 2009.
[42] United Nations. Risk Management in the Systems of Normative Regulation, United Nations, New York, Geneva, 2014.

[43] United Nations. Practical Manual on Transfer Pricing for Developing Countries, United Nations, New York, 2021. 1.

[44] K. Brychta, M. Ištok, A. Sulik-Górecka, V. Poreisz. Transfer Pricing in V4 Countries, VUTIUM, Brno, 2020. 